\title{
Evaluation of the nutritive value of sugarcane residues inoculated with fungus Fomes sp
}

\author{
Evaluación del valor nutritivo de residuos de caña de azúcar \\ inoculado con hongo Fomes sp
}

\author{
Alex Olivera $\mathrm{D},{ }^{1}$ M.Sc, Emilio Aranda I, ${ }^{1 *}$ Ph.D, Jesus Ramos ${ }^{1},{ }^{1} \mathrm{Ph} . \mathrm{D}$, \\ Luis Vargas V, ${ }^{1}$ Ph.D, Juan Zaldivar C, ${ }^{1}$ Ph.D, German Mendoza M, ${ }^{2}$ Ph.D.
}

${ }^{1}$ Colegio de Postgraduados, Campus Tabasco. Periferico Carlos A. Molina, Km 3.5. Carretera CardenasHuimanguillo. H. Cardenas, Tabasco, Mexico C.P. 86500. ${ }^{2}$ Universidad Autonoma Metropolitana-Xochimilco Biotechnology Department, Xochimilco, DF. Mexico. *Correspondence: earanda@colpos.mx

Received: April 2013; Accepted: November 2013.

\begin{abstract}
Objective. Improve the nutritional value of mechanized sugarcane residues inoculating the fungus Fomes sp. EUM1. Materials and methods. The fungus Fomes was inoculated according to a $0,0.1$, 0.2 , and $0.3 \%(\mathrm{w} / \mathrm{v})$ treatment and incubated at a temperature of $35^{\circ} \mathrm{C}$ for 7,10 and 13 days. It was obtained DM, OM, CP, ash, NDF and ADF and the effective degradation of DM, NDF and ADF, with an experimental factorial design of $3 \times 3$ and a completely randomized design. The factors were growing days in an Erlenmeyer flask ( 7,10 , and 13) and inoculum percentage $(0.1,0.2$ and 0.3$)$. The data were analyzed with the SAS statistical package. Results. Statistical significance was found in the interaction of the fungus growing days by percentage of inoculum, in the variables: DM, CP and $\mathrm{pH}$. The NDF and ADF factor differed in the percentage of inoculum. Effective degradation showed significant for the same type of interaction in all the variables studied. Conclusions. The inoculation of the fungus increased ADF degradation by only $0.2 \%$ of the inoculum percentage, without any effect on effective degradation due to the use of soluble fractions at the beginning of the incubation. It is considered that the degradation occurs in stages that are important to consider for determining treatments to maximize the beneficial effects of the fungus in terms of ruminant nutrition.
\end{abstract}

Key words: Enzymes, fermentation, ruminants (Source: DeCS).

\section{RESUMEN}

Objetivo. Mejorar el valor nutritivo de los residuos de cosecha mecanizada de la caña de azúcar inoculando el hongo Fomes sp. EUM1. Materiales y métodos. El hongo Formes se inoculó de acuerdo al tratamiento $0,0.1,0.2$ y $0.3 \%(\mathrm{p} / \mathrm{v})$, incubándose a una temperatura de $35^{\circ} \mathrm{C}$ durante 7,10 y 13 días. Se obtuvo la MS, MO, PC, cenizas, FDN y FDA y la degradación efectiva de la MS, FDN y FDA; con un diseño experimental de tipo factorial $3 \times 3$, con un diseño experimental completamente al azar. Los factores fueron días de crecimiento en matraz Erlenmeyer $(7,10,13)$ y porcentajes de inclusión $(0.1,0.2$ y 0.3$)$. Los datos se analizaron con el paquete estadístico SAS. Resultados. Se encontró 
significancia estadística para la interacción días de crecimiento del hongo por porcentaje de inóculo, en las variables MS, PC y pH. La FDN y la FDA presentaron diferencias para el factor porcentaje de inóculo. La degradación efectiva mostró significancia para el mismo tipo de interacción, en todas las variables estudiadas. Conclusiones. La inoculación del hongo aumentó la degradación de la FDA, únicamente al $0.2 \%$ de porcentaje de inclusión, sin un efecto sobre la degradación efectiva, debido a la utilización de fracciones solubles al inicio de la incubación. Se considera que la degradación se produce por etapas que son importante considerar para la determinación de tratamientos que maximicen los efectos benéficos del hongo en términos de la nutrición de rumiantes.

Palabras clave: Enzimas, fermentación, rumiantes (Fuente: DeCS).

\section{INTRODUCTION}

One of the fundamental problems in the feeding of ruminants in the tropics is the low availability of dry matter in pastures in the rainy and dry seasons; contrary to what occurs in the rainy season. In the state of Tabasco, Mexico, there are 29,112 Ha planted with sugar cane, of which $28,705 \mathrm{Ha}$ are harvested, with a total production of $1,780,551 \mathrm{~T}$ of sugarcane and an average of $62.03 \mathrm{~T} / \mathrm{Ha}(1)$. After the mechanized harvesting, the amount of residues (leaves, tips, stems, buds) remaining in the field is $18 \mathrm{~T} / \mathrm{DM} / \mathrm{Ha}(2)$, which could be used when there is a shortage of fodder. However, the main factors limiting the digestion of sugarcane residues in ruminants are: low protein content and high-fiber content (2).

Solid fermentation can be defined as a process where microorganisms grow on solid material with very low water levels. The material may be byproducts generated by agricultural and forestry practices (3-6). This type of fermentation improves certain nutritional features of agricultural yields when used as substrates (7). The species of the genus Fomes is mesophilic, since the optimal temperatures for its growth are between 20 and $36^{\circ} \mathrm{C}$, very few species are heat-tolerant. The fungus Fomes sp. EUM1 is capable of growing in a temperature ranging from 20 to $40^{\circ} \mathrm{C}$; however, its optimum growth temperature has been found to be $30^{\circ} \mathrm{C}(8)$.

In order to reduce the fibrous components and increase the digestibility of low-quality agricultural byproducts, biotechnological fermentation processes have been used with fungus that produces enzymes such as xylanases, laccases and cellulases $(9,10)$. Therefore, the objective of this study was to improve the nutritional value of mechanized sugarcane residues by inoculating the fungus Fomes sp. EUM1.

\section{INTRODUCCIÓN}

Uno de los problemas fundamentales en la alimentación de rumiantes en el trópico es la baja disponibilidad de la materia seca en los pastos en la época de lluvias y estiaje; contrario de lo que sucede en la época de lluvias. En el estado de Tabasco, México, hay 29.112 ha sembradas de caña de azúcar, de las cuales se cosechan 28.705 ha, con una producción total de 1.780 .551 t de caña molederas y un promedio de $62.03 \mathrm{t} / \mathrm{ha}$ (1). Después de la cosecha mecanizada, la cantidad de residuos (hojas, puntas, tallos, cogollo) que queda en el campo es de $18 \mathrm{t} / \mathrm{MS}$ / ha (2), lo cual pudiera ser utilizada en la época de escasez de forrajes. Sin embargo, los principales factores que limitan la digestión de los residuos de la caña de azúcar en los rumiantes son: su bajo contenido de proteína y alto contenido de fibra (2).

La fermentación sólida puede definirse como un proceso donde los microorganismos crecen sobre el material sólido con muy pocos niveles de agua. El material puede ser subproductos generados por las prácticas agrícolas y forestales (3-6). Este tipo de fermentación mejora algunas características nutricionales de los esquilmos agrícolas cuando son utilizados como sustratos (7). La especie del género Fomes es mesofílica, ya que sus temperaturas óptimas de crecimiento se encuentran entre los 20 y $36^{\circ} \mathrm{C}$, muy pocas especies son termo tolerantes. El hongo Fomes sp. EUM1 es capaz de crecer en un rango de temperatura que va desde los 20 a los $40^{\circ} \mathrm{C}$; sin embargo, se ha determinado su temperatura óptima de crecimiento a $30^{\circ} \mathrm{C}(8)$.

Para reducir los componentes fibrosos e incrementar la digestibilidad de los subproductos agrícolas de baja calidad, se han utilizado procesos biotecnológicos de fermentación con hongos que producen enzimas como xilanasas, lacasas y celulasas $(9,10)$. Por lo anterior, el objetivo del presente trabajo fue mejorar el valor nutritivo de los residuos mecanizados de la caña de azúcar inoculando el hongo Fomes sp. EUM1. 


\section{MATERIALS AND METHODS}

Study site. The study was carried out in the Food and Animal Science laboratories of Colegio de Postgraduados, Campus Tabasco, located in Cardenas, Tabasco, Mexico.

Substrate. The residue of the mechanized sugarcane harvest from a freshly cut channel of the variety CP 20-86 was used in town C-31 of Cardenas, Tabasco, Mexico. It is mainly composed of: buds, green leaves, pods and dry leaves. It was grinded in a Nogueira mill model DPM-500.1.2.4, powered by a petrol engine obtaining particles between 2 and $5 \mathrm{~cm}$ in diameter.

Inoculum. The fungus Fomes of the white patch Fomes sp. EUM1 was used, which has the potential to produce lignocellulolytic enzymes, which were provided by Universidad Autonoma Metropolitana, Campus Iztapalapa, Mexico DF.

Culture medium. Malt extract was used for the propagation of the macro myketos as a source of carbon and nitrogen extracted from yeast. The culture medium was prepared by dissolving the following components in distilled water: $40 \mathrm{~g} / \mathrm{L}$ of malt extract, $3 \mathrm{~g} / \mathrm{L}$ of yeast extract and $18 \mathrm{~g} / \mathrm{L}$ of bacteriological agar (4). This was sterilized in an autoclave for 15 minutes at $120^{\circ} \mathrm{C}$. The sterile medium was poured into Petri dishes, which were subsequently inoculated with mycelium in a disc of $0.6 \mathrm{~cm}$ in diameter. They were incubated at $30^{\circ} \mathrm{C}$ for 7 days.

Determination of the DM of the biomass. This was performed within 7 days of the growth of the mycelium in the culture medium, and the result is used, solely, for the determination of the amount of mycelia for inoculation per treatment. The biomass was separated from the agar by washing the Petri dish with distilled boiling water. Once the biomass was separated, it was placed in a paper filter (Whatman No. 541) and dried in a forced air stove SHEL $L A B$ at $60^{\circ} \mathrm{C}$ until a constant weight was achieved. The value of the DM of the biomass was obtained by weight difference.

Cultivation in solid medium. Erlenmeyer flasks of $500 \mathrm{ml}$ were used and $105 \mathrm{~g}$ of dry substrate (mechanized sugarcane residue), $315 \mathrm{ml}$ of distilled water and $1.05 \mathrm{~g}$ of urea were adding 24 $\mathrm{h}$ before being inoculation $(11,12)$. Subsequently, all flasks were sterilized in an autoclave $\left(120^{\circ} \mathrm{C}\right.$, $15 \mathrm{psi}, 20 \mathrm{~min}$ ) and inoculated with the fungus in accordance with the treatment $0 \%, 0.1 \%(\mathrm{w} / \mathrm{v})$, $(1.05 \mathrm{~g}), 0.2 \%(\mathrm{w} / \mathrm{v}),(2.1 \mathrm{~g}), 0.3 \%(\mathrm{w} / \mathrm{v}),(3.15$ g) of the substrate used. These were incubated at a temperature of $35^{\circ} \mathrm{C}$ for 7,10 and 13 days.

\section{MATERIALES Y MÉTODOS}

Sitio de estudio. El trabajo fue realizado en los laboratorios de Alimentos y Ciencia Animal del Colegio de Postgraduados, Campus Tabasco, ubicados en Cárdenas, Tabasco, México.

Sustrato. Se utilizó el residuo de la cosecha mecanizada de la caña de azúcar de un cañal recién cortado de la variedad CP 20-86 en el poblado C-31 de Cárdenas, Tabasco, México. Compuestos principalmente por: cogollos, hojas verdes, hojas secas y vainas. El cual fue molido en un molino marca Nogueira modelo DPM500.1.2.4, con motor de gasolina obteniendo partículas entre 2 y $5 \mathrm{~cm}$ de diámetro.

Inóculo. Se utilizó el hongo Fomes de la podredumbre blanca Fomes sp. EUM1, que tiene potencial de producir enzimas lignocelulolíticas, el cual fue proporcionado por la Universidad Autónoma Metropolitana, Campus Iztapalapa, México, DF.

Medio de cultivo. Para la propagación del macromiceto, se utilizó extracto de malta como fuente de carbono y como fuente de nitrógeno extracto de levadura. El medio de cultivo se preparó disolviendo los siguientes componentes en agua destilada: extracto de malta $40 \mathrm{~g} / \mathrm{L}$, extracto de levadura $3 \mathrm{~g} / \mathrm{L}$ y agar bacteriológico $18 \mathrm{~g} / \mathrm{L}(4)$. Se esterilizó en autoclave durante 15 minutos a $120^{\circ} \mathrm{C}$. El medio estéril se vertió en cajas de Petri, en las cuales posteriormente fueron inoculados con un disco de $0.6 \mathrm{~cm}$ de diámetro con micelio. Se incubaron a $30^{\circ} \mathrm{C}$ durante 7 días.

Determinación de la MS de la biomasa. Se realizó a los 7 días del crecimiento del micelio en el medio de cultivo y el resultado se utilizó, únicamente, para la determinación de la cantidad de micelio a inocular por tratamiento. La biomasa se separó del agar lavando la caja Petri con agua destilada en ebullición. Una vez separada la biomasa se colocó en papel filtro (Whatman No. 541) y se secó en estufa de aire forzado SHEL LAB a $60^{\circ} \mathrm{C}$ hasta lograr un peso constante. El valor de la MS de la biomasa se obtuvo por diferencia de peso.

Cultivo en medio sólido. Se utilizaron Erlenmeyers de $500 \mathrm{ml}$, se les agregó 105 $\mathrm{g}$ de sustrato seco (residuo mecanizado de caña de azúcar), $315 \mathrm{ml}$ de agua destilada y $1.05 \mathrm{~g}$ de urea $24 \mathrm{~h}$ antes de ser inoculada $(11,12)$. Posteriormente, todos los matraces se esterilizaron en autoclave $\left(120^{\circ} \mathrm{C}, 15 \mathrm{psi}, 20 \mathrm{~min}\right)$ y se inocularon con el hongo de acuerdo con el tratamiento $0 \%, 0.1 \%(\mathrm{p} / \mathrm{v}),(1.05 \mathrm{~g}), 0.2 \%$ 
Chemical analysis. The dry matter (DM) and crude protein (CP) were determined according to the methodology proposed by the AOAC (12), as well as by the fractioning of the fiber in neutral detergent fiber (NDF) and acid detergent fiber (ADF), using the methodology proposed by Van Soest (13). The variable OM was calculated by a difference of 100 - ash; the variable $\mathrm{pH}$ was measured taking $10 \mathrm{~g}$ of the residues from each flask and placing the same in a $250 \mathrm{ml}$ Erlenmeyer flask, where $90 \mathrm{ml}$ of distilled water was added and stirred for $30 \mathrm{~min}$. Then, it filtered and the $\mathrm{pH}$ was immediately measured with a Conductronic $\mathrm{pH} 10$ portable meter.

Effective degradation rate. For the determination of the effective degradation (ED) of the DM (DMED), OM (OMED), NDF (NDFED) and ADF (ADFED), at $96 \mathrm{~h}$, a differential equations system was developed from the concepts of effective degradation described by Noguera (14) and indicated below:

$\mathrm{dS} / \mathrm{dt}=-$-Degradation;

$\mathrm{dSE} / \mathrm{dt}=$-Effective_degradation-Passage; $\mathrm{dD} /$ $\mathrm{dt}=$ Degradation; $\mathrm{dDE} / \mathrm{dt}=$ Effective_degradation; Passage $=\mathrm{kp} * \mathrm{SE}$;

Degradation $=k d * S$;

Effective_degradation $=\mathrm{kd} * \mathrm{SE}$; .

With the initial values:

INIS $=100-f S D ;$ INISE $=100-f S D$;

$\mathrm{INID}=\mathrm{fSD} ; \mathrm{INIDe}=\mathrm{fDE} ; \mathrm{fSD}=50$;

$\mathrm{kd}=0.03 ; \mathrm{kp}=0.03$

Where:

$\mathrm{S}=$ Substrate for the calculation of degradation; $\mathrm{SE}=$ Substrate for the calculation of effective degradation;

$\mathrm{D}=$ Degraded material;

$\mathrm{DE}=$ Degraded material taking into account the passage rate (Effective degradation);

$\mathrm{fSD}=$ Soluble fraction;

INIX = Initial value of the variable of state $x$.

The model was adjusted for the estimation of the soluble fraction (fSD) and degradation rate (td) from the in situ degradation curves of each treatment subject to chemical analysis. The ED corresponded to the value of the variable with the same name at $96 \mathrm{~h}$. To obtain the degradation curves nylon bags were incubated with the material to be evaluated and were taken out at $6,12,24,48,72$ and 96 h using the methodology described by Noguera (14). The program used for the adjustment of the parameters, and the obtaining of the ED was the Berkeley Madonna v8.01 (15).

Experimental design and statistical analysis. For the variables of chemical composition (DM, $(p / v),(2.1 \mathrm{~g}), 0.3 \%(p / v),(3.15 \mathrm{~g})$ del sustrato utilizado. Se incubaron a una temperatura de $35^{\circ} \mathrm{C}$ durante 7,10 y 13 días.

Análisis químico. Se determinó la materia seca (MS) y proteína cruda (PC) de acuerdo con la metodología propuesta por la AOAC (12), así como el fraccionamiento de la fibra en fibra detergente neutra (FDN) y fibra detergente ácida (FDA), utilizando la metodología propuesta por Van Soest (13). La variable de MO se calculó por diferencia de 100 - \% ceniza, la variable de $\mathrm{pH}$ se midió tomando $10 \mathrm{~g}$ de los residuos de cada matraz, se depositaron en un matraz Erlenmeyer de $250 \mathrm{ml}$, en donde se le adicionó $90 \mathrm{ml}$ de agua destilada y se agitó durante $30 \mathrm{~min}$. Posteriormente, se filtró y se midió inmediatamente el $\mathrm{pH}$ con un medidor portátil Conductronic Modelo pH 10.

Tasa de degradación efectiva. Para la determinación de la degradación efectiva (DE) de la MS (DEMS), MO (DEMO), FDN (DEFDN) y FDA (DEFDA), a las $96 h$, se desarrolló un sistema de ecuaciones diferenciales a partir de los conceptos de degradación efectiva descritos por Noguera (14), y descrito a continuación:

$\mathrm{dS} / \mathrm{dt}=$-Degradación;

$\mathrm{dSE} / \mathrm{dt}=$-Degradación_efectiva-Pasaje;dD/ $\mathrm{dt}=$ Degradación; $\mathrm{dDE} / \mathrm{dt}=$ Degradación_efectiva; Pasaje $=\mathrm{kp} * \mathrm{SE}$;

Degradación $=k d * s$;

Degradación_efectiva $=\mathrm{kd} * \mathrm{SE}$; .

Con los valores iniciales:

INIS $=100-f S D$; INISE $=100-f S D$;

INID $=f S D ;$ INIDe $=f D E ; f S D=50$;

$\mathrm{kd}=0.03 ; \mathrm{kp}=0.03$

Dónde:

$\mathrm{S}=$ Substrato para cálculo de la degradación;

$\mathrm{SE}=$ Substrato para cálculo de la degradación efectiva;

$\mathrm{D}=$ Material degradado;

$\mathrm{DE}=$ Material degradado tomando en cuenta la tasa de pasaje (Degradación efectiva);

$\mathrm{fSD}=$ Fracción soluble;

INIX $=$ Valor inicial de la variable de estado $\mathrm{x}$.

El modelo fue ajustado para la estimación de la fracción soluble (fSD) y tasa de degradación (td) a partir de las curvas de degradación in situ de cada tratamiento al que se le hizo un análisis químico. La DE correspondió al valor de la variable del mismo nombre al tiempo $96 \mathrm{~h}$. Para la obtención de las curvas de degradación se incubaron en un toro fistulado bolsas de nylon con el material a evaluar y se fueron sacando en horarios de 6, 12, 24, 48, 72, y 96 h, utilizando la metodología descrita por Noguera 
$\mathrm{OM}, \mathrm{CP}, \mathrm{NDF}$ and $\mathrm{ADF}$ ) and $\mathrm{pH}$, a $3 \times 3$ factorial experiment was conducted; where the factor $A$, days of growth of the fungus, was evaluated at three levels: 7, 10, and 13 days; factor B, percentage of inoculum, was studied at three levels: $0.1,0.2$ and $0.3 \%(w / v)$. The combination of the two factors and their levels generated a total of nine treatments that were housed in a completely randomized experimental design with two replications. A variance analysis was performed for each of the variables of chemical composition according to the experimental design proposed and the following linear model:

$Y_{i j k}=\mu+a_{i}+Y_{j}+n_{i j}+e_{i j k} ;$ for $\mathrm{i}=1,2,3 ; \mathrm{j}=1,2$, $3 ; \mathrm{k}=1,2$;

Where:

$Y_{i j k}$ represents the observation at level i of factor $A$ with level $j$ of factor $B$ and replication $j$;

$\mu$ is the general mean;

$a_{i}$ is equivalent to the fixed effect of level $i$ of factor A;

$Y_{j}$ is the fixed effect of level $j$ of factor $B$;

$\Pi_{i j}$ is the effect of the interaction $A \times B$;

and $\mathrm{e}_{\mathrm{ijk}}$ is the random error.

Subsequently, for the interaction of the days of growth of the fungus (A) with the inclusion percentage (B) and the main effects that showed to be significant $(p<0.05)$, a multiple comparison of means test was conducted using the Tukey method $(16,17)$. The information was processed using the statistical analysis software SAS version 9.3 and the procedures glm and mixed (17).

For ED (DMED, OMED, NDFED, and ADFED) at $96 \mathrm{~h}$, a $3 \times 3$ factorial experiment was conducted; where the factor $A$, days of inoculation, was evaluated at three levels: 7, 10, and 13 days; factor $B$, inclusion percentage, was studied at three levels: $0.1,0.2$ and $0.3 \%(w / v)$. The combination of the two factors and their levels generated a total of nine treatments, which were housed in an experimental design of complete randomized blocks, where each block was conformed by an animal. For each of the ED variables, a variance analysis was performed according to the experimental design proposed and the following linear model:

$Y_{i j k}=\mu+a_{i}+Y_{j} j+\delta_{k}+n_{j k}+e_{i j k} ;$ for $i=1,2 ; j=1,2$, $3 ; \mathrm{k}=1,2,3$;

\section{Where}

$Y_{i j k}$ represents the observation of animal or block $i$, at level $j$ of factor $A$ with level $k$ of factor $B$;

$\mu$ is the general mean;

$a_{i}$ is equivalent to the random effect of animal $i$, $Y_{j}$ is the effect of level $j$ of factor $A$;

$\delta_{k}$ is the fixed effect of level $k$ of factor $B$;
(14). El programa utilizado para el ajuste de los parámetros y la obtención de la DE fue Berkeley Madonna v8.01 (15).

Diseño experimental y análisis estadístico. Para las variables de composición química (MS, MO, PC, FDN y FDA) y el $\mathrm{pH}$, el experimento fue de tipo factorial $3 \times 3$; donde el factor $A$, días de crecimiento del hongo, fue evaluado en tres niveles: 7, 10, y 13 días; el factor B, porcentaje de inóculo, fue estudiado en tres niveles: 0.1 , 0.2 , y $0.3 \%(p / v)$. La combinación de los dos factores y sus niveles generó un total de nueve tratamientos, mismos que fueron alojados en un diseño experimental completamente al azar con dos repeticiones. Para cada una de las variables de composición química, se realizó un análisis de varianza de acuerdo con el diseño experimental propuesto y al siguiente modelo lineal:

$Y_{i j k}=\mu+a_{i}+Y_{j}+\Pi_{i j}+e_{i j k} ;$ para i $=1,2,3 ; j=1,2$, 3; $\mathrm{k}=1,2$;

Dónde:

$Y_{i j k}$ representa la observación en el i-ésimo nivel del factor A con el j-ésimo nivel del factor B y la j-ésima repetición;

$\mu$ es la media general;

$a_{i}$ equivale al efecto fijo el i-ésimo nivel del factor $\mathrm{A}$;

$Y_{j}$ es el efecto fijo del j-ésimo nivel del factor B; $\Pi_{i j}$ es el efecto de la interacción A X B;

$\mathrm{y}_{\mathrm{ijk}}$ es el error aleatorio.

Posteriormente, para la interacción días de crecimiento del hongo (A) por porcentaje de inóculo (B) y efectos principales que resultaron significativos $(p<0.05)$ se realizó una prueba de comparación múltiple de medias mediante el método de Tukey $(16,17)$. La información fue procesada con ayuda del software para análisis estadístico SAS versión 9.3 y los procedimientos glm y mixed (17).

Para las DE (DEMS, DEMO, DEFDN y DEFDA), a $96 \mathrm{~h}$, el experimento fue de tipo factorial 3X3; donde el factor $A$, días de inoculación, fue evaluado en tres niveles: 7, 10, y 13 días; el factor B, porcentaje de inclusión, fue estudiado en tres niveles: $0.1,0.2$, y $0.3 \%(p / v)$. La combinación de los dos factores y sus niveles generó un total de nueve tratamientos, los cuales fueron alojados en un diseño experimental de bloques completos al azar, donde cada bloque estuvo conformado por un animal. Para cada una de las variables de $D E$, se realizó un análisis de varianza de acuerdo con el diseño experimental propuesto y al siguiente modelo lineal:

$\mathrm{Y}_{\mathrm{ijk}}=\mu+\mathrm{a}_{\mathrm{i}}+\mathrm{Y}_{-} \mathrm{j}+\delta_{\mathrm{k}}+\Pi_{\mathrm{jk}}+\mathrm{e}_{\mathrm{ijk}} ;$ para $\mathrm{i}=1,2 ; \mathrm{j}=1$, 2,$3 ; \mathrm{k}=1,2,3$; 
$\Pi_{j k}$ is the effect of the interaction A X B; $\mathrm{y}_{\mathrm{ijk}}$ is the random error.

Subsequently, for the days of inoculation interaction $(A)$ by inclusion percentage (B) and the main effects that resulted significant $(p<0.05)$, a multiple comparison of means test was conducted using the Tukey method (16). The information was processed using the statistical analysis software SAS version 9.3 and the procedures glm and mixed (17).

\section{RESULTS}

The results of the chemical analyses showed a statistical significance for the interaction $A$ $X B$, days of growth of the fungus $(A)$ by the inoculum percentage $(B)$, in the variables: DM $(p=0.0221), C P(p=0.0022)$, and $\mathrm{pH}(p=0.0170)$. The variables that showed statistical significance for factor $A$, days of fungal growth, were NDF $(p=0.0082)$ and ADF $(p=0.0185)$; while the variables $O M$ and ashes were not significant $(p>0.05)$ in all sources of variation. The DM only showed significant differences between the days of growth of the fungus of $0.2 \%(\mathrm{w} / \mathrm{v})$ of the inclusion percentage, while $\mathrm{CP}$ and $\mathrm{pH}$ in $0.3 \%$ of growth. Table 1 shows the results of the variables with interactions. The global means of the variables were: $D M=29.47, O M=90.58$, $\mathrm{CP}=5.19, \mathrm{NDF}=72.92, \mathrm{ADF}=45.34, \mathrm{Ash}=9.42$ and $\mathrm{pH}=7.11$. The NDF showed significant differences between day 7 (76.46\%), day 10 $(71.55 \%)$ and day $13(70.75 \%)$ of incubation. Similarly, the ADF showed differences between day $7(49.50 \%)$, day $10(43.72 \%)$ and day 13 (42.81\%).

All variables which degradation was studied showed statistical significance for the interaction of the days of inoculation $(A)$ and the percentage of inclusion $(B), D M(p=0.0007)$, OM $(p=0.001)$,

Table 1. Effect of the concentration of the fungus Fomes sp. EUM1 and days of growth in the residues of the mechanized harvesting of sugarcane in its content of DM, CP and $\mathrm{pH}$

\begin{tabular}{lcccc}
\hline Variable & $\begin{array}{c}\text { Days of } \\
\text { growth }\end{array}$ & \multicolumn{3}{c}{ Percentage of inoculum } \\
& $\mathbf{0 . 1}$ & $\mathbf{0 . 2}$ & $\mathbf{0 . 3}$ \\
\hline DM (\%) & 7 & $31.24^{\mathrm{a}}$ & $33.82^{\mathrm{a}}$ & $29.06^{\mathrm{a}}$ \\
& 10 & $30.58^{\mathrm{a}}$ & $28.75^{\mathrm{b}}$ & $30.89^{\mathrm{a}}$ \\
& 13 & $29.35^{\mathrm{a}}$ & $23.81^{\mathrm{c}}$ & $27.72^{\mathrm{a}}$ \\
& $\mathrm{E} . \mathrm{E}$. & 1.6284 & & \\
$\mathrm{CP}(\%)$ & 7 & $5.28^{\mathrm{a}}$ & $5.69^{\mathrm{a}}$ & $5.07^{\mathrm{a}}$ \\
& 10 & $4.22^{\mathrm{b}}$ & $6.19^{\mathrm{a}}$ & $5.07^{\mathrm{a}}$ \\
& 13 & $3.93^{\mathrm{b}}$ & $6.00^{\mathrm{a}}$ & $5.27^{\mathrm{a}}$ \\
$\mathrm{pH}$ & $\mathrm{E} . \mathrm{E}$. & 0.2272 & & \\
& 7 & $8.26^{\mathrm{a}}$ & $6.46^{\mathrm{a}}$ & $7.43^{\mathrm{a}}$ \\
& 10 & $8.58^{\mathrm{a}}$ & $6.35^{\mathrm{a}}$ & $5.63^{\mathrm{b}}$ \\
& 13 & $8.44^{\mathrm{a}}$ & $6.43^{\mathrm{a}}$ & $6.44^{\mathrm{b}}$ \\
& $\mathrm{E}$ & 0.3417 & & \\
\hline
\end{tabular}

abc Means with different superscript in the same column differ in $p<0.05$. donde

$Y_{i j k}$ representa la observación en el i-esimo animal o bloque, en el j-ésimo nivel del factor $A$ con el k-ésimo nivel del factor $B$;

$\mu$ es la media general;

$a_{i}$ equivale al efecto aleatorio del i-ésimo animal, $Y_{j}$ es el efecto del j-ésimo nivel del factor $A$;

$\delta_{k}$ es el efecto fijo del k-ésimo nivel del factor $B$;

$\Pi_{j k}$ es el efecto de la interacción A X B;

$y e_{i j k}$ es el error aleatorio.

Posteriormente, para la interacción días de inoculación (A) por porcentaje de inclusión (B) y efectos principales que resultaron significativos $(p<0.05)$ se realizó una prueba de comparación múltiple de medias mediante el método de Tukey (16). La información fue procesada con ayuda del software para análisis estadístico SAS versión 9.3 y los procedimientos glm y mixed (17).

\section{RESULTADOS}

Los resultados de los análisis químicos mostraron significancia estadística para la interacción A X B, días de crecimiento del hongo $(A)$ por porcentaje de inóculo (B), en las variables: $M S(p=0.0221)$, PC $(p=0.0022)$ y $p H(p=0.0170)$. Las variables que presentaron significancia estadística para el factor $A$, días de crecimiento del hongo, fueron FDN $(p=0.0082)$ y FDA $(p=0.0185)$; mientras que las variables $\mathrm{MO}$ y cenizas no fueron significativas ( $p>0.05)$ en todas las fuentes de variación. La MS, únicamente, presentó diferencias significativas entre los días de crecimiento del hongo al $0.2 \%$ ( $p / v)$ de porcentaje de inclusión, mientras que la $\mathrm{PC}$ y $\mathrm{pH}$ al $0.3 \%$ de crecimiento. En la tabla 1 se pueden ver los resultados de las variables que presentaron interacciones. Las medias globales de las variables fueron: $M S=29.47 \%$, $\mathrm{MO}=90.58 \%, \mathrm{PC}=5.19 \%, \mathrm{FDN}=72.92 \%$, FDA $=45.34 \%$, Cenizas $=9.42 \%$ y $\mathrm{pH}=7.11$. La FDN presentó diferencias significativas entre los 7 días de incubación (76.46\%) los 10 (71.55\%) y 13 días $(70.75 \%)$ de incubación. De igual forma, la FDA presentó diferencias entre el 7 día $(49.50 \%)$ y los $10(43.72 \%)$ y 13 días $(42.81 \%)$.

Todas las variables, a las que se les estudiaron sus degradaciones DE, mostraron significancia estadística para la interacción días de inoculación (A) por porcentaje de inclusión (B), MS $(p=0.0007), M O(p=0.001), \operatorname{FDN}(p=0.0035)$ y FDA $(p=0.0419)$. En todos los casos se presentaron, únicamente, interacciones y diferencias estadísticas significativas entre los tiempos de incubación del inóculo al 0.2\% ( $p / v)$ de porcentaje de inclusión (Tabla 1), con una disminución evidente de los valores de estas variables al aumentar los días de incubación 
NDF $(p=0.0035)$ and ADF $(p=0.0419)$. In all cases there were only interactions and significant statistical differences between the times of incubation of the inoculum at $0.2 \%$ $(w / v)$ of the percentage of inclusion (Table $1)$, with an apparent decrease in the values of such variables as the days of incubation of the inoculum increased. The study of degradation kinetics showed that these declines were due to a reduction of td that went from 0.0054 to $0.0022,0.0060$ to $0.0025,0.00620 .0025$ and 0.0059 to 0.0023 , for, DM, OM, NDF and ADF (Table 2, 3), respectively, and not due to changes in the amounts of $\mathrm{fSD}$, which showed marginal differences, except in the case of the ADF that was from 0.72 to $10.57 \%$ at day 7 to 13 of incubation. The means of all fSD were, 21.05, $26.24,12.81$ and $5.36 \%$, for DM, OM, NDF and ADF, respectively.

Table 2. Effect of the concentration of the fungus Fomes sp. EUM1 and days of growth in residues of the mechanized harvesting of sugarcane in the effective degradation of DM, OM, NDF and ADF.

\begin{tabular}{ccccc}
\hline \multirow{2}{*}{ Variable } & $\begin{array}{c}\text { Days of } \\
\text { growth }\end{array}$ & \multicolumn{3}{c}{ Percentage of inoculum } \\
& 0.1 & 0.2 & 0.3 \\
\hline DM (\%) & 7 & $52.68^{\mathrm{a}}$ & $53.31^{\mathrm{a}}$ & $53.73^{\mathrm{a}}$ \\
& 10 & $54.89^{\mathrm{a}}$ & $44.58^{\mathrm{b}}$ & $53.31^{\mathrm{a}}$ \\
& 13 & $52.04^{\mathrm{a}}$ & $35.76^{\mathrm{c}}$ & $56.57^{\mathrm{a}}$ \\
OM (\%) & E.E. & 1,9756 & & \\
& 7 & $58.27^{\mathrm{a}}$ & $58.26^{\mathrm{a}}$ & $59.29^{\mathrm{a}}$ \\
& 10 & $59.92^{\mathrm{a}}$ & $50.06^{\mathrm{b}}$ & $58.44^{\mathrm{a}}$ \\
& 13 & $57.02^{\mathrm{a}}$ & $42.27^{\mathrm{c}}$ & $60.60^{\mathrm{a}}$ \\
NDF (\%) & E.E. & $1,7872^{\mathrm{a}}$ & & \\
& 7 & $52.72^{\mathrm{a}}$ & $51.78^{\mathrm{a}}$ & $53.03^{\mathrm{a}}$ \\
& 10 & $55.34^{\mathrm{a}}$ & $41.50^{\mathrm{b}}$ & $53.11^{\mathrm{a}}$ \\
& 13 & $50.52^{\mathrm{a}}$ & $32.67^{\mathrm{c}}$ & $54.05^{\mathrm{a}}$ \\
ADF (\%) & 7 & 2,5218 & & \\
& 7 & $40.11^{\mathrm{a}}$ & $43.78^{\mathrm{a}}$ & $45.91^{\mathrm{a}}$ \\
& 10 & $49.56^{\mathrm{a}}$ & $33.34 \mathrm{~b}^{\mathrm{a}}$ & $46.01^{\mathrm{a}}$ \\
& 13 & $40.73^{\mathrm{a}}$ & $27.93^{\mathrm{b}}$ & $47.49^{\mathrm{a}}$ \\
& E.E. & 4.24 & & \\
\hline
\end{tabular}

abc Means with different superscript in the same column differ in $\mathrm{p}<0.05$.

\section{DISCUSSION}

The study of DM resulted in a pattern similar to that found in all variables where ED was studied (DM, OM, NDF and ADF). In these variables, differences were only found between the days of growth of the fungus at $0.2 \%(w / v)$ of the inclusion percentage, with a reduction of DM and ED as the days of incubation increased from day 7 to 13 . In the case of the concentration of NDF and ADF, the same trend was observed, but for all percentages of inclusion. Similar results have been found in sugarcane bagasse treated with the strain Trichoderma viride M5-2, where a decrease in the NDF, ADF and $\mathrm{Hc}$ of 5,3 and $2 \%$ were observed $(18,19)$. The decrease of DM could be due to the growth of the mycelium during the days of solid-state fermentation and synthesis of organic acids at the expense of a del inóculo. El estudio de la cinética de la degradación, mostró que estas disminuciones se debieron a una reducción de las td que fueron de 0.0054 a $0.0022,0.0060$ a $0.0025,0.0062$ a 0.0025 , y de 0.0059 a 0.0023 , para, MS, MO, FDN y FDA (Tablas 2, 3), respectivamente, y no debido a cambios en las cantidades de fSD, las cuales presentaron diferencias marginales, excepto para el caso de la FDA que fue de 0.72 a $10.57 \%$ de 7 a 13 días de incubación. Las medias de todas las fSD fueron, 21.05, 26.24, 12.81 y $5.36 \%$, para MS, MO, FDN y FDA, respectivamente.

Table 3. Effect of the concentration of the fungus Fomes sp. EUM1 and days of growth in residues of the mechanized harvesting of sugarcane in the rate of degradation of DM, OM, NDF and ADF.

\begin{tabular}{ccccc}
\hline Variable & $\begin{array}{c}\text { Days of } \\
\text { growth }\end{array}$ & \multicolumn{3}{c}{ Percentage of inoculum } \\
& $\mathbf{0 . 1}$ & $\mathbf{0 . 2}$ & $\mathbf{0 . 3}$ \\
\hline DM (\%) & 7 & 0.0054 & 0.0054 & 0.0055 \\
& 10 & 0.0059 & 0.0037 & 0.0058 \\
OM (\%) & 13 & 0.0042 & 0.0022 & 0.007 \\
& 7 & 0.0058 & 0.006 & 0.0062 \\
& 10 & 0.0065 & 0.0041 & 0.0064 \\
NDF (\%) & 13 & 0.0047 & 0.0025 & 0.0063 \\
& 7 & 0,0061 & 0.0062 & 0.0064 \\
ADF (\%) & 10 & 0,0064 & 0.0044 & 0.0065 \\
& 13 & 0,0046 & 0.0025 & 0.0072 \\
& 7 & 0.0046 & 0.0059 & 0.0057 \\
& 10 & 0.0059 & 0.0037 & 0.0058 \\
& 13 & 0.0034 & 0.0023 & 0.0065 \\
\hline
\end{tabular}

\section{DISCUSIÓN}

El estudio de la MS presentó un patrón similar a lo encontrado en todas las variables en las que se estudiaron las DE (MS, MO, FDN y FDA). En estas variables solamente se encontraron diferencias entre los días de crecimiento del hongo al $0.2 \%$ $(\mathrm{p} / \mathrm{v})$ de porcentaje de inclusión, con una reducción de la MS y de la DE conforme aumentaron los días de incubación del día 7 al 13. En el caso de la concentración de la FDN y FDA se observó la misma tendencia, pero para todos los porcentajes de inclusión. Resultados similares se han encontrado en el bagazo de caña tratada con la cepa Trichoderma viride M5-2, donde se observó una disminución de la FDN, FDA y Hc en 5,3 y $2 \%(18,19)$. La disminución de la MS pudo deberse al crecimiento del micelio durante los días de fermentación en estado sólido y la síntesis de ácidos orgánicos a costa de una eficiencia de conversión pobre a partir de la hemicelulosa (Hc). La disminución de la Hc como consecuencia de crecimiento del hongo ha sido reportada previamente en ensilaje de caña de azúcar tratada con Pleurotus sapidus, aunque acompañada con un incremento y no con una disminución de la MS (11). 
poor conversion efficiency from hemicellulose $(\mathrm{Hc})$. The decrease in $\mathrm{Hc}$ as a result of the growth of the fungus has been previously reported in sugarcane silage treated with Pleurotus sapidus, although accompanied by an increase and not a decrease in DM (11).

The difference mentioned above may be due to the development phase of the fungus, the type of substrate used, the types of enzymes produced, the percentage of inclusion or an interaction of factors (20). This would explain why there were no differences between the days of incubation for the inclusion percentage of 0.1 and $0.3 \%$ $(\mathrm{w} / \mathrm{v})$ in DM and OM, as opposed to NDF and ADF. A too fast or too slow relative growth, as a consequence of the percentage of inclusion of the fungus, would leave outside the range of study sections where there are biological and statistical differences between treatments, since periods of stability can be found in all processes involving degradation, at both the beginning and end of these process. At the beginning because microorganisms require a time to adapt to the new conditions and at the end due to the end of the substrates (20).

For practical purposes, neither of these ends is suitable for the use of the fungus, since at the beginning it has not had time to produce enough enzymes to decrease degradation and at the end the substrate is already exhausted, they are not substrates that can be exploited by the ruminant. The significant differences found in concentrations of $\mathrm{CP}$ and $\mathrm{pH}$ at 0.1 and $0.3 \%(\mathrm{w} / \mathrm{v})$ of inoculation, respectively, indicate the existence of processes different from those observed at $0.2 \%(\mathrm{w} / \mathrm{v})$, and that the statistical similarities found between the levels of 0.1 and $0.3 \%(\mathrm{w} / \mathrm{v})$ are a consequence of the final balance of the processes and not of identical compositions. Studies similar to this where specific chemical compounds such as $\mathrm{Hc}$ and true protein are evaluated could help to understand the changes that occur during the growth of the fungus.

In contrast to this study, in two experiments with the fungus Pleurotus sp., obtained from lignocellulose residues, the content of $\mathrm{CP}$ increased in $10-15 \%(21,22)$. Likewise, Pal et al (9) reported an increase in CP in wheat straw fermented with the fungus Trametes versicolor and Pleurotus ostreatus.

Decreases in ED of observed in inclusion percentages of $0.2 \%(\mathrm{w} / \mathrm{v})$ in all treatments (Table 2) could be caused, similarly for DM, and as it has been previously reported in experiments with Fomes sp. EUM1, because the fungus is using $\mathrm{Hc}$ as a source of energy for growth (22), before rising the production of enzymes capable
La diferencia mencionada anteriormente, puede ser debido a la fase en la que se encontraba el desarrollo del hongo, al tipo de sustrato utilizado, a los tipos de enzimas producidas, al porcentaje de inclusión o a una interacción de factores (20). Lo anterior explicaría por qué no se encontraron diferencias entre los días de incubación para los porcentaje de inclusión de 0.1 y $0.3 \%(\mathrm{p} / \mathrm{v})$, en la MS y MO, pero si en el caso de la FDN y FDA. Un crecimiento relativo demasiado rápido o demasiado lento, a consecuencia del porcentaje de inclusión del hongo, dejaría fuera del rango de estudio secciones donde existen diferencias biológicas y estadísticas entre los tratamientos, ya que en todos los procesos donde se involucran degradaciones, al principio y al final de estos se pueden encontrar períodos de estabilidad. Al principio porque los microorganismos requieren de un tiempo para adaptarse a las nuevas condiciones y al final por la terminación del o los sustratos (20).

Para fines prácticos, ninguno de estos extremos es adecuado para la utilización del hongo, ya que al inicio, este todavía no ha tenido tiempo para producir suficientes enzimas para disminuir la degradación y, al final, el sustrato ya se agotó o no quedan sustratos que pueda ser aprovechados por el rumiante. Las diferencias significativas encontradas en las concentraciones de la PC y pH al 0.1 y $0.3 \%(\mathrm{p} / \mathrm{v})$ de inoculación, respectivamente, indican la existencia de procesos diferentes a los observados al $0.2 \%(p / v), y$ a que las similitudes estadísticas encontradas entre los niveles de 0.1 y $0.3 \%(\mathrm{p} / \mathrm{v})$ son una consecuencia del saldo final de los procesos y no a composiciones idénticas. Estudios similares al presente, en donde se evalúen compuestos químicos específicos como la Hc y proteína verdadera, ayudarían a comprender los cambios que se producen durante el crecimiento del hongo.

En contraste con este trabajo, en dos experimentos con el hongo Pleurotus sp., obtenido de residuos lignocelulósicos, se aumentó el contenido de PC de $10-15 \%$ (21,22). Asimismo, Pal et al (9) reportaron un incremento de la PC en paja de trigo fermentada con los hongos Trametes versicolor y Pleurotus ostreatus.

Las disminuciones en las DE observadas a los porcentaje de inclusión de $0.2 \%(\mathrm{p} / \mathrm{v})$ en todos los tratamientos (Tabla 2) pudieron deberse, al igual que para la MS, y como ha sido reportado previamente en experimentos con Fomes sp EUM1, a que el hongo está utilizando la Hc como fuente de energía para el crecimiento (22), antes de elevar la producción de enzimas con capacidad degradadora de lignina (22), con un pico máximo de producción enzimática de celulasas y xilanasas entre los días 9 y $15(9,10)$. Debido a que los tipos de enzimas encontradas en el hongo de estudio son celulasas, xilanasas y lacasas (22), similares a los encontrados en otros trabajos $(9,10)$, esto podría indicar dinámicas similares en la 
of degrading lignin (22), with a peak of enzyme production of cellulases and xylanases between day 9 and $15(9,10)$. Since the types of enzymes found in the fungus under study are cellulases, xylanases and laccases (22), similar to those found in other studies $(9,10)$, this could indicate similar dynamics in the production of enzymes. In the same vein, Salcedo et al (23) reported an increase in the degradation of $\mathrm{Hc}$ in sugarcane residues treated with commercial ligninolytic enzymes previously using a delignification treatment.

Yan et al (24) found an increase in the in situ digestibility of DM (DMDI) in alfalfa and rice straw using exogenous enzymes. Similarly, in another experiment, an increase of DMDI was observed in a hay compound using 15 and 30\% of the cellulose, xylanasa and fibrolytic enzymes (25), which contrasts with what was found in this study, since no increase of ED and/or td was found in any treatment (Table 2 and 3). Contrary to what was previously reported, the ED of DM (DMED) was reduced in $33 \%$ and td in $59 \%$, when the inclusion percentage was $0.2 \%(\mathrm{w} / \mathrm{v})$, and the incubation time increased from 7 to 13 days.

In the case of NDF, Membrillo et al (26) found an increase in the degradation of this fraction using the fungus Pleurotus ostreatus IE- 8 and different substrate particle sizes, where the substrate was sugarcane bagasse. In alfalfa hay and rye grass treated with fibrolytic enzymes, Pinos et al (27) reported, in the same way, an increase in the in situ digestibility of NDF (NDFDI) and ADF (ADFDI) of 6 and $72 \mathrm{~h}$. Likewise, in another study an increase in NDFDI was found using treatments with Saccharomyces cerevisiae and Aspergillus oryzae in alfalfa hay (28). However, in this study, both the NDF and the ADF showed a behavior similar to that previously described for DM. Therefore, only at a percentage of inclusion of $0.2 \%(\mathrm{w} / \mathrm{v})$, the NDFDI decreased in $37 \%$ and td in $60 \%$, while the ADFED, at that same percentage, dropped $36 \%$ and $\mathrm{td} 61 \%$, when the incubation time increased from 7 to 13 days. The above represents something contrary to what was expected based on previously published reports. In this study, the decrease in DMED, OMED, NDFED y ADFED, in the only level of the inclusion percentage $(0.2 \% \mathrm{w} / \mathrm{v})$ where significant differences were reported, occurred as a consequence of the decrease in td as the days of incubation increased, since as mentioned above, changes in fSD were marginal (except for ADF) and that td showed marked decreases close to $60 \%$.

In this study, the effect of the inoculation of the fungus, in terms of DM concentration, its fractions producción de enzimas. En el mismo sentido, Salcedo et al (23) reportaron un aumento en la degradación de la Hc en residuos de caña de azúcar tratados con enzimas ligninolíticas comerciales utilizando previamente un tratamiento de deslignificación.

Yan et al (24) encontraron un aumento en la digestibilidad in situ de la MS (DIMS) en alfalfa y paja de arroz, utilizando enzimas exógenas. De igual forma, en otro experimento se observó un incremento de la DIMS en un compuesto de heno utilizando el 15 y $30 \%$ de las enzimas fibrolíticas celulasa y xylanasa (25), lo cual contrasta con lo encontrado en este trabajo, ya que, en ningún tratamiento se encontró un incremento de la DE y/o td (Tabla 2 y 3). Al contrario de lo reportado previamente, la DE de la MS (DEMS) se redujo $33 \%$ y la td $59 \%$, cuando el porcentaje de inclusión fue $0.2 \%(\mathrm{p} / \mathrm{v})$, y el tiempo de incubación aumentó de 7 a 13 días.

En el caso de la FDN, Membrillo et al (26) encontraron un aumento en la degradación de esta fracción utilizando el hongo Pleurotus ostreatus IE-8 y diferentes tamaños de partículas del sustrato, donde el sustrato fue el bagazo de caña de azúcar. En heno de alfalfa y pasto ballicos tratados con enzimas fibrolíticas, Pinos et al (27) reportaron, de igual forma, un aumento en la digestibilidad in situ de la FDN (DIFDN) y FDA (DIFDA) de 6 y 72 h. Asimismo, en otro trabajo, se encontró un aumento de la DIFDN utilizando tratamientos de Saccharomyces cerevisiae y Aspergillus oryzae en heno de alfalfa (28). Sin embargo, en el presente trabajo, tanto la FDN como la FDA tuvieron un comportamiento similar a lo descrito previamente para la MS. Por lo consiguiente, únicamente, al $0.2 \%(\mathrm{p} / \mathrm{v})$ de porcentaje de inclusión, la DEFDN se redujo $37 \%$ y la td $60 \%$, mientras que la DEFDA, a ese mismo porcentaje, se redujo $36 \%$ y la td $61 \%$, cuando el tiempo de incubación aumentó de 7 a 13 días. Lo anterior representa algo contrario a lo que se esperaba basado en los reportes previamente publicados. En el presente trabajo, la disminución de las DEMS, DEMO, DEFDN and DEFDA, en el único nivel de porcentaje de inclusión $(0.2 \%$ $\mathrm{p} / \mathrm{v}$ ) donde se reportaron diferencias significativas, fueron como consecuencia de la disminución de las td al aumentar los días de incubación, ya que, como se mencionó anteriormente, los cambios de las fSD fueron marginales (exceptuando para la FDA) y a que las td presentaron disminuciones muy marcadas cercanas al $60 \%$.

En este trabajo, el efecto de la inoculación del hongo, en términos de concentración de MS, sus fracciones y degradación, pudo deberse al equilibrio de los diferentes procesos que tienen lugar en cada una de las etapas de crecimiento. Es posible que al nivel del $0.2 \%(\mathrm{p} / \mathrm{v})$ de porcentaje de inclusión, la utilización de fracciones de fácil degradación, como la Hc, que se ha observado en otros trabajos 
and degradation, could be due to the balance of the different processes that take place in each of the growth stages. It is possible that the level of $0.2 \%(\mathrm{w} / \mathrm{v})$ of the percentage of inclusion, the use of easily degradable fractions, such as the $\mathrm{Hc}$ observed in other studies (11), could contribute to the decrease of the degradation of all fractions as the days of growth increased, since a fraction with high degradation is reduced leaving harddegradation fractions. In this regard, the maximum time of growth of the fungus ( 13 days) could have limited the manifestation of enzymes on the fiber, since previous reports recommend up to 15 days $(9,10)$ or more of fungal growth $(11)$ to attain a significant effect. Even in these circumstances, the increase of 0.72 to $10.57 \%$ in the ADF's fSD, found at a level of $0.2 \%(\mathrm{w} / \mathrm{v})$ of the percentage of inclusion as the time of inoculation increased, is a clear indicator of the effect that the enzymes of the fungus have on the fiber, as well as of the need to increase the time of incubation for this effect to be reflected on ED.

Under the conditions in which this study was conducted, it is concluded that the inoculation of the fungus Fomes sp. EUM1 in mechanized harvesting of sugarcane waste has an effect on the ADF that is not reflected in the increase of degradation, due to the use of a highly degradable compound such as $\mathrm{Hc}$, which is used as a source of energy at the beginning of its growth, although this effect only occurred at a level of $0.2 \%(\mathrm{w} / \mathrm{v})$ of the inclusion percentage. Also, it is concluded that degradation occurs in stages that must be considered for the determination of the levels of the percentage of inclusion or incubation times where the beneficial effects of the fungus are maximized in terms of ruminant nutrition. Finally, the results obtained from the analysis of the ED of the different fractions of the material studied and their subsequent comparison with their corresponding fSD and td, demonstrated the usefulness of this methodology to study the processes that take place during the establishment, growth and production of enzymes by the fungus. The above must be taken into consideration for the planning of new experiments.

\section{Acknowledgements}

To the National Council of Science and Technology (CONACYT) for the scholarship granted for the study of the postgraduate studies on Agro-Food Production in the Tropics of Colegio de Postgraduados, Campus Tabasco. To UAM Ixtapalapa for its contribution of the strain that was used in this research. To the research lines of Colegio de Postgraduados LPI2 and LPI5 for the financial support for reagents and laboratory materials. The effective degradation model was developed for this study by Mr. Luis Manuel Vargas-Villamil.
(11) pudiera contribuir a la disminución de la degradación de todas las fracciones conforme aumentaron los días de crecimiento, ya que se reduce una fracción que tiene una alta degradación, quedando fracciones de difícil degradación. En este mismo sentido, el tiempo de crecimiento máximo del hongo (13 días) pudo haber limitado la manifestación de las enzimas sobre la fibra, debido a que reportes previos recomiendan hasta 15 días $(9,10)$ o más de crecimiento del hongo $(11)$ para alcanzar un efecto significativo. Aún en estas circunstancias, el incremento del 0.72 al $10.57 \%$ de la fSD de la FDA, encontrada al nivel de $0.2 \%(\mathrm{p} / \mathrm{v})$ de porcentaje de inclusión al aumentar el tiempo de inoculación, es un claro indicador del efecto que tienen las enzimas del hongo sobre la fibra, así como de la necesidad de incrementar el tiempo de incubación para que este efecto se refleje en la DE.

Bajo las condiciones en que se llevó este estudio, se concluye que la inoculación del Hongo Fomes sp. EUM1 en los residuos de cosecha mecanizada de la caña de azúcar tiene un efecto en la FDA que no se ve reflejado en el incremento de la degradación, debido a la utilización de compuesto altamente degradables, como la Hc, que son utilizados como fuente de energía al inicio de su crecimiento, aunque este efecto sólo fue manifestado al nivel de $0.2 \%(\mathrm{p} / \mathrm{v})$ de porcentaje de inclusión. También, se concluye que la degradación se produce por etapas que son importantes considerar para la determinación de niveles de porcentaje de inclusión o de tiempos de incubación donde se maximicen los efectos benéficos del hongo en términos de la nutrición de rumiantes. Finalmente, los resultados obtenidos del análisis de la DE de las diferentes fracciones del material estudiado y su posterior comparación con su correspondiente fSD y td, demostraron la utilidad de esta metodología para estudiar los procesos que tienen lugar durante el establecimiento, crecimiento y producción de enzimas por parte del hongo. Lo anterior, habría que tomarse en cuenta para la planificación de nuevos experimentos.

\section{Agradecimientos}

Al Consejo Nacional de Ciencia y Tecnología (CONACYT) por la beca otorgada para el estudio del posgrado Producción Agroalimentaria en el Trópico del Colegio de Postgraduados, Campus Tabasco. A la UAM Ixtapalapa, por el aporte de la cepa que se utilizó en dicha investigación. A las líneas de Investigación del Colegio de Postgraduados LPI2 y LPI5 por el apoyo financiero para reactivos y materiales de laboratorio. El modelo de degradación efectiva fue desarrollado para este trabajo por el Dr. Luis Manuel Vargas-Villamil. 


\section{REFERENCES}

1. Sistema Integral de Información Agroalimentaria y Pesquera [en línea]. 2011. (acceso noviembre del 2013). URL Disponible en: http://www.siap.gob.mx/ index.php?option $=$ com_wrapper\&view $=w r$ apper\&Itemid $=351$.

2. Lal R. Soil quality impacts of residue removal for bioethanol production. Soil Tillage Res 2009; 102:233-241.

3. Aranda EM, Ruiz P, Mendoza GD, Marcoff CF, Ramos JA, Elías A. Cambios en la digestión de tres variedades de caña de azúcar y sus fracciones de fibra. Rev Cubana Cienc Agric 2004 ; 38:137-144.

4. Fernandez JA, Henao JM, Pedrosa AM, Quevedo B. Inmovilización de hongos ligninoliticos para la remoción de colorantes negro reactivos. Rev Colomb Biotechnol 2009; 11:59-72.

5. Krishna C. Solid state fermentation systems: An overview. Crit Rev Biotechnol 2005; 25:1-30.

6. Arora DK, Bridge DP, Bhatnagar D. Handbook of Fungal Biotechnology. New York: CRC Press; 2004.

7. Peláez AA, Meneses M, Miranda RL, Megias RM, Barcena GR, Loera O. Ventajas de la fermentación sólida con Pleurotus sapidus en ensilaje de caña de azúcar. Arch Zootec 2008; 57:25-33.

8. Ordaz A, Favela E, Meneses M, Mendoza G, Loera O. Hyphal morphology modification in the thermal adaptation by the white rot fungus Fomes sp. EUM1. J Basic Microbiol $2011 ; 52: 167-174$.

9. Pal M, Calvo AM, Terrón MC, González AE. Solid-state fermentation of sugarcane bagasse with Flammulina velutipes and Trametes versicolor. J Microbiol Biotechnol $1995 ; 11: 541-545$.

10. Sánchez A, Ysunza F, Beltrán M, Esqueda M. Cultivo del hongo comestible Pleurotus sobre residuos vitivinícolas y su manejo pos cosecha. [Tesis de Maestría]. Hermosillo, México: Universidad de Sonora; 2005.
11. Peláez A, Meneses M, Miranda A, Ayala M, Crosby M, Loera $\mathrm{O}$ et al. Enzimas fibrolíticas producidas por fermentación en estado sólido para mejorar los ensilajes de caña de azúcar. Agrociencia 2011; 45:675-685.

12. O.A.C. Official Methods of Analysis (18th Ed). Washington D.C.: O.A.C International; 2005.

13. Van Soest PJ, Robertson JP, Lewis BA. Symposium: Carbohydrate methodology, metabolism and nutritional implications in dairy caltle. J Dairy Sci 1991; 74:3583-3597.

14. Noguera RR, Posada SL. Modelación de la cinética de degradación de alimentos para rumiantes. Rev Col Cienc Pec 2007; 20:174182.

15. Berkeley Madonna (programa de computadora). Versión 8.0. Berkeley: University of California; 2000.

16. Steel GDR, Torrie HJ, Dickey DA. Principles and procedures of statistics a biometrical approach. 3ra Ed. Michigan, USA: McGraw Hill Companies, Inc; 1997.

17. SAS/STAT ${ }^{\circledR}$ (programa de computadora). Versión 9.3. SAS Institute Inc; 2013.

18. Valiño EC, Elías A, Torres V, Carrasco T, Albelo N. Mejoramiento de la composición del bagazo de caña de azúcar por la cepa Trichoderma viride M5-2 en un biorreactor de fermentación en estado sólido. Rev Cubana Cienc Agric 2004; 38:145-153.

19. García Y, Ibarra A, Valiño EC, Dustet JC, Oramas A, Albelo N. Estudio de un sistema de fermentación sólida con agitación en la biotransformación del bagazo de caña de azúcar por la cepa Trichoderma viride M5-2. Rev Cubana Cienc Agric 2002; 36:265-270.

20. Arce O. Producción de extractos de enzimáticos a partir de Formes sp EUM1 y su evaluación en condiciones ruminales. [Tesis de Doctorado]. México: Universidad Autónoma Metropolitana, Unidad Iztapalapa; 2012.

21. Arias GM, Bueno G, Betancourt D, Álvarez I, González AL. Biotransformación de Residuos Lignocelulósicos con Hongos Pleurotus. Rev CENIC Cienc Biol 2005; 36:1-7. 
22. Akinfemi A, Ogunnwole OA, Lapido $M K$, Adu OA, Osineye OMES. Enhancement of the nutritive value of maize leaf treated with white-rot fungi: Pleurotus sajorcaju and Pleurotus pulmonarius, and the effects on chemical composition and in vitro digestibility. Prod Agric Technol 2009; $1: 106-110$.

23. Salcedo M, López J, Flores P. Evaluación de enzimas para la hidrólisis de residuos (hojas y cogollos) de la cosecha caña de azúcar. Dyna 2010; 78:182-190.

24. Yan $H$, Son $Y$, Beauchemin KA. Effects of exogenous enzymes on ruminal fermentation and degradability of alfalfa hay and rice straw. Asian-Aust J Anim Sci 2011; 24:56-64.

25. Giraldo LA, Carro MD, Ranilla MJ, Tejido $M L$. Influence of fibrolytic enzymes on in vitro methane production and rumen fermentation of a substrate containing $60 \%$ of grass hay. Livestock Research for Rural Development [en línea] 2007 (acceso 15 de noviembre del 2013); 19: Article 185. URL disponible en: http://www.Irrd.org/ Irrd19/12/gira19185.htm
26. Membrillo I, Sánchez C, Meneses M, Favela E, Loera O. Particle geometry affects differentially substrate composition and enzyme profiles by Pleurotus ostreatus growing on sugar cane bagasse. J Microbiol Biotechnol 2010; 2:1581-1586.

27. Pinos J, González S, Mendoza G, Bárcena $R$, Cobos M. Efecto de enzimas fibroliticas exógenas en la digestibilidad in vitro de la pared celular de heno de alfalfa (Medicago sativa) o de ballico (Lolium perenne). Interciencia 2002; 27:28-32.

28. Miranda RLA, Mendoza MGD, Bárcena-Gama JR, González MSS, Ferrara R, Ortega CME et al. Effect of Saccharomyces cerevisiae or Aspergillus oryzae cultures and NDF level on parameters of ruminal fermentation. Anim Feed Sci Technol 1996; 63:289-296. 